Arq. Bras. Med. Vet. Zootec., v.67, n.3, p.723-726, 2015

\title{
Bilateral hydrosalpinx in a mare - a case report
}

[Hidrossalpinge bilateral em égua - relato de caso]

\author{
S.F. Rechsteiner, R.F. Rodrigues, L.A. Cruz
}

Historep - Instituto de Biologia - UFPel - Pelotas, RS

\begin{abstract}
During a research visit for tissue collection at an abattoir located in Pelotas, Brazil, one female genital tract showed both enlarged oviducts. The reproductive tract was collected and analyzed. Occluded uterine tubes and an increase in the organ volume due to the large amount of fluid in the organ lumen were the macroscopic findings. Three samples, corresponding to isthmus, ampulla and infundibulum from each uterine tube and one sample from the endometrium were collected. Samples were fixed in Bouin's solution and processed in light microscopy. Microscopically a decrease in the number of folds and also an increase in the lumen of the organ were observed, mainly in the ampulla and infundibulum. The epithelial lining of the uterine tubes ranged from ciliated to simple squamous. Inflammatory cells were observed between the epithelial cells and in the lamina propria. Hydrosalpinx is difficult to diagnose and can be a cause of infertility in the mare.
\end{abstract}

Keywords: fluid accumulation, uterine tubes, oviducts, equine, female

\section{RESUMO}

Durante uma visita de pesquisa para coleta de tecido em um abatedouro localizado na cidade de Pelotas, Brasil, foi observado um trato genital com aumento do tamanho dos ovidutos. O trato reprodutivo foi coletado e analisado. Os achados macroscópicos observados foram tubas uterinas ocluídas e com aumento do volume do órgão devido à grande quantidade de líquido na luz do órgão. Três amostras, correspondendo a istmo, ampola e infundíbulo, e uma amostra do endométrio foram coletadas. As amostras foram fixadas em solução de Bouin e processadas para microscopia de luz. Microscopicamente foi observada uma diminuição no número de pregas e um aumento do lúmen do órgão, principalmente na ampola e no infundíbulo. $O$ epitélio de revestimento das tubas uterinas variou de cilíndrico ciliado a pavimentoso simples. Células inflamatórias foram observadas entre as células epiteliais e na lâmina própria das tubas uterinas. A hidrossalpinge é difícil de ser diagnosticada e pode ser uma causa de infertilidade na égua.

Palavras-chave: acúmulo de fluido, tubas uterinas, ovidutos, equinos, fêmea

\section{INTRODUCTION}

The oviducts (Fallopian tubes, uterine tubes) are long tortuous ducts that measure 20 to $30 \mathrm{~cm}$ in length when fully extended in mares (Brinsko et al., 2011). Each uterine tube consists of an expansive infundibulum covering the ovary's ovulation fossa, a highly tortuous ampulla about $6 \mathrm{~mm}$ in diameter, and a less tortuous isthmus half the diameter of the ampulla (Kainer, 2011). The wall of the uterine tube consists of three

Recebido em 1 de agosto de 2013

Aceito em 9 de janeiro de 2015

E-mail: sandrafiala@yahoo.com.br layers: mucosa, muscularis and serosa (McEntee, 1990). The mucosa has longitudinal folds projecting into the lumen (McEntee, 1990). The luminal surface topography of equine uterine tubes was studied by scanning electron microscopy by Stallheim et al., (1975). The authors observed that the main types of epithelial cells in the mare's uterine tubes were secretory and ciliated. Both types were more active during estrus. Cilia were observed in both the infundibular and the ampular parts of the uterine tube, but ciliated cells were more numerous than 
secretory cells on the surface of the fimbriae (Stalheim et al., 1975). The muscularis increases in thickness from the infundibulum to the uterotubal junction (McEntee, 1990).

The diagnostic and therapeutic options for tubal disorders in the mare are limited and therefore pathological conditions of these structures may be more prevalent than reported in the literature (Köllmann et al., 2011). Investigation and flushing of the oviduct are possible using the laparoscopic lateral flankapproach. Laparoscopic flushing could become a practical method for diagnosis and therapy of oviduct disorders (Köllmann et al., 2011).

Hydrosalpinx is a build up of fluid inside the infundibulum and appears to be rare in horses, different from what occurs in cows and sows (McEntee, 1990). Hydrosalpinx sometimes occurs as a result of external pressure from adhesions obstructing the lumen (McEntee, 1990) or of segmental aplasia (Hinrichs et al., 1984). Arthur (1958), in a study in which reproductive tracts were collected in the slaughterhouse observed a frequency of unilateral hydrosalpinx $0.25 \% \quad(2 / 792)$, while

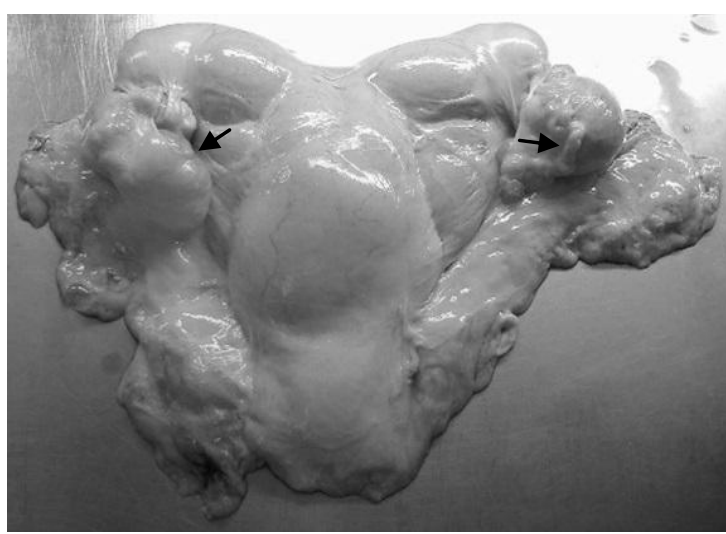

Figure 1. Mare reproductive tract showing enlarged oviducts (arrows).

Three samples, corresponding to istmus, ampulla and infundibuluam were collected from each uterine tube. Samples were fixed in Bouin's solution and processesd to light microscopy. The slides were stained with Hematoxilin-eosin. The uterus was sectioned and a sample of the endometrium was collected and processed in the same way in order to analyze inflammatory and degenerative changes (Kenney, 1978). During
Henry and Vandeplassche (1981) studying 2297 reproductive tracts of mares did not observe any cases of hydrosalpinx.

The hydrosalpinx can be a cause of infertility in mares where other changes in the reproductive organs were not observed and due to its difficult diagnosis goes unnoticed, decreasing the reproductive efficiency in this species.

The aim of this paper was to describe a bilateral hidrosalpinx in a mare.

During a research visit for tissue collection at an abattoir located in Pelotas, Brazil, one female genital tract showed both enlarged oviducts. The entire reproductive tract was collected and analyzed by the Morphology Department at the Universidade Federal de Pelotas. Macroscopically it was observed that the uterine tubes were occluded and with an increase in the volume due to the large amount of fluid in the organ lumen (Figure 1).

Uterine tubes were separated from the reproductive tract, measured and pictures were taken (Figure 2).

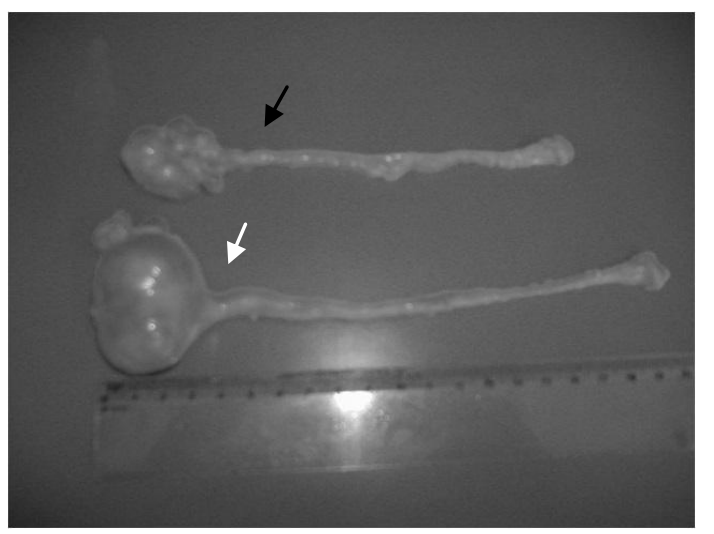

Figure 2. Enlarged right (black arrow) and left oviducts (white arrow) separated from the mare reproductive tract and dissected.

the analysis of the slides a decrease in the number of folds and also an increase in the lumen of the organ (Fig. 3 and 4) were observed, which varied according to the region of the organ. The portion of the organ which should have a greater number of folds didn't, due to the fact that it was the portion with the highest volume of fluid and therefore with a very distended lumen. 


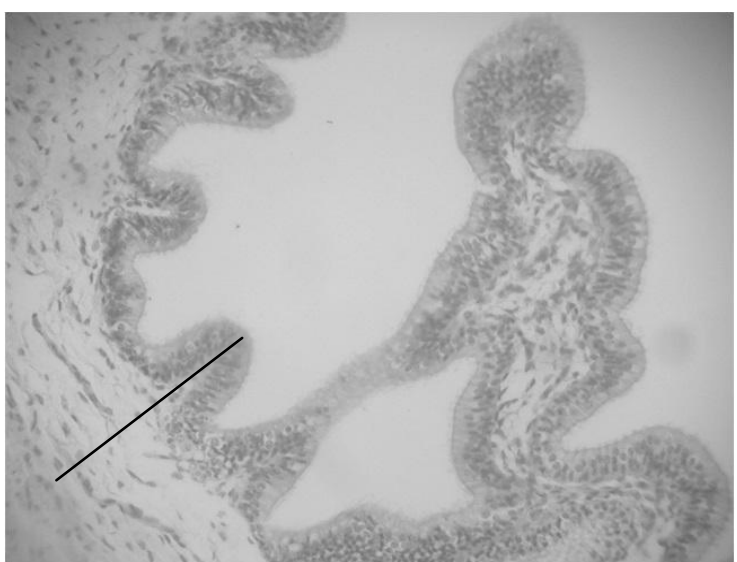

Figure 3. Mare. Epithelium and lamina propria (black line) in the uterine tube ampulla-isthmus junction.

Some alterations were observed in the mucosa. The epithelial lining of the uterine tubes ranged from columnar ciliated to simple squamous. The simple squamous epithelium was seen in areas corresponding to ampulla and infundibulum (Figure 5), which were the regions with the more distended lumen, and regions where the epithelium found in normal mares is columnar intermittently ciliated.

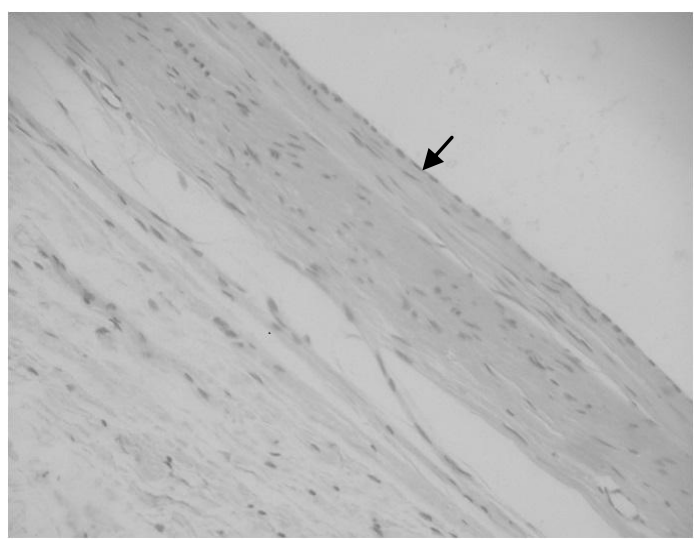

Figure 5. Mare. Simple squamous epithelium (arrow) Simple epithelium appears to replace the cylindrical epithelium that is typical of this regionin in uterine tube

Inflammatory cells (neutrophils and eosinophils were observed between the epithelial cells, and in the lamina propria (plasm cells). The other layers (muscle and serosa) showed no alterations.

A satisfactory glandular population was observed in the endometrium. Chronic inflammation with widespread presence of lymphocytes, plasma

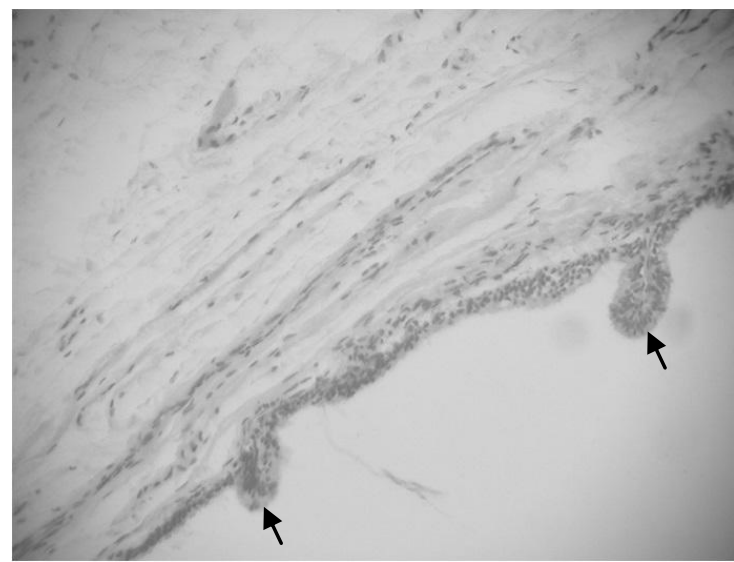

Figure 4. Mare. Decrease in the number of folds arrows) in the uterine tube infundibulum mucosa.

cells and eosinophils, was observed but degenerative changes were not found, and the endometrium was classified as Grade IIa.

From the 198 reproductive tracts collected during the trial only one had the presence of hydrosalpinx. Saltiel et al., (1986) evaluating macroscopically uterine tubes from 325 mares, observed that $285(87.69 \%)$ of the mares had at least one macroscopic lesion. Hydrosalpinx, bilateral salpingitis and oophoritis were diagnosed in a mare with concurrent lymphosarcoma (Hawkins, 1986) Although rare (Arthur, 1958; Henry and Vandeplassche, 1981), hydrosalpinx is of great importance once it can occlude the uterine tube preventing the capture of the oocyte, especially when it occurs bilaterally, as noted in this finding. The mucosa of the oviduct is formed by primary, secondary and tertiary folds. The mucosa consists of a layer of columnar epithelial cells and the epithelium consists of ciliated and non-ciliated cells (McEntee, 1990). The uterine tubes observed showed a decrease in the number of folds, which no longer exist in the area at the end of the ampulla and in the infundibulum. Changes in the lining epithelium were seen, demonstrating the occurrence of metaplasia, a tissue replacement that occurs in an attempt to adapt when the organ is injured.

The adhesion of sperm to epithelial cells in the isthmus is thought to prevent premature capacitation and increase the lifespan of the sperm, resulting in a sperm reservoir awaiting the opportunity for release to fertilize the ovum 
(Brinsko et al., 2011). The areas closest to the ovary, (ampulla and infundibulum) showed, in this mare, a squamous simple epithelium, probably because of the great distension that affected the organ, which demonstrates loss of function in this area, since ciliated and secretory cells had disappeared. Both ciliated and secretory cells play important functions in maintenance of ovum, sperm cells and embryo.

Due to the bilateral hidrosalpinx the mare was unable to reproduce. The diagnosis of this alteration is difficult, since it is not easy to evaluate the uterine tubes and the hidrosalpínx can be confused with paraovaric cysts or ovarian structures (Hinrichs et al., 1984). One alternative to diagnose this condition could be the use of laparoscopic flushing (Köllmann et al., 2011). Vets and owners should take into account that an infertile mare, with unknown cause, may be suffering from such a change.

The hydrosalpinx, although a rare finding in the mare, can be a cause of infertility, especially when it occurs on a bilateral basis.

\section{REFERENCES}

ARTHUR, G.H. An analysis of the reproductive function of mares based on post-mortem examination. Vet. Rec., v.70, p.682-86, 1958

BRINSKO, S.P.; BLANCHARD, T.L.; VARNER, D.D. et al. Reproductive anatomy of the mare. Manual of Equine Reproduction Mosby, Ed. Elsevier, 2011. $332 \mathrm{p}$.
HAWKINS, K.L. Bilateral salpingitis, hydrosalpinx and oophoritis in a mare. Cornell Vet., v.76, p.38-48, 1986.

HENRY, M.; VANDEPLASSCHE, M. Pathology of the oviduct in mares. Vlaams Diergeneeskundig Tijdschrift, v.50, p.301-325, 1981.

HINRICHS, K.; KENNEY, R.M.; HURTGEN, J.P. Unilateral hydrosalpinx and absence of the infundibulum in a mare. Theriogenology, v.22, p.571577,1984

KAINER, R.A. Internal Reproductive Anatomy. In: ANGUS, O.; MCKINNON, A.O.; SQUIRES, E.L. et al. Equine Reproduction Second Edition. Edited by Blackwell Publishing Ltd., 2011. p.1582- 1597.

KENNEY, R.M. Cyclic and pathologic changes of the mare endometrium as detected by biopsy, with a note on early embryonic death. J. Am. Vet. Med. Assoc., v.172, p.241-262, 1978.

KÖLLMANN, M.; RÖTTING A.; HEBERLING A.; SIEME, H. Laparoscopic techniques for investigating the equine oviduct. Equine Vet. J., v.43, p.106-111, 2011.

McENTEE, K. The uterine tube. In: McEntee, K. Reproductive Pathology of Domestic Animals. London: Academic Press, 1990. p.94-105.

SALTIEL, A.; PÁRAMO, R.; MURCIA, C.; TOLOSA J. Pathologic findings in the oviducts of mares. Am. J. Vet. Res., v.47, p.594-557, 1986.

STALHEIM, O.H.; GALLAGHER, J.E.; DEYOE, B.L. Scanning electron microscopy of the bovine, equine, porcine, and caprine uterine tube (oviduct). Am. J. Vet. Res., v. 36, p.1069-1075, 1975. 